\section{A Ditadura Militar no jornalismo: uma abordagem a partir do conceito de lugar de memória}

Ana Regina R̂EGO'

Resumo: A Ditadura Militar retorna do passado como um corpo morto (CERTEAU, 2011), cinquenta anos após o golpe que irrompeu violentamente com o sistema democrático vigente, embora frágil. Naquele contexto os meios de comunicação e o jornalismo trabalharam, em um primeiro momento, de forma orquestrada objetivando o que acreditavam como defesa da democracia; posteriormente, mudaram de posição e foram perseguidos. Poucos conseguiram se manter trabalhando ativamente, um deles foi Carlos Castello Branco em sua Coluna do Castello no JB. Nesse contexto é que analisamos o jornalismo como um lugar de memória tendo como referencial o pensamento de Nora $(1993,1984,2008,2011)$ e Ricouer (2012), e a partir da análise da atuação do jornalismo naquele panorama, sobretudo, de Carlos Castello Branco, do Jornal O Dia e da Revista Veja.

Palavras-chave: Ditadura Militar; Jornalismo; Lugar de memória; Carlos Castello Branco

\section{La Dictadura Militar en el Periodismo: un enfoque basado en el concepto de 'lu- gar de memoria'}

Resumen: La Dictadura Militar vuelve del pasado como un cuerpo muerto (CERTEAU, 2011), 50 años después del golpe de Estado que se rompió con el sistema democrático vigente, aunque todavía frágil. En ese contexto,

\footnotetext{
1 Jornalista. Mestre em Comunicação e Cultura. Doutora em Comunicação. Consultora $A d$ hoc voluntária das instituições do terceiro setor: Instituto de Comunicação e Cultura- ICC, Fundação de Apoio a Cultura do Piauí - FUNDAPI, Associação dos Amigos da Orquestra Sinfônica de Teresina. Colunista do Jornal O Dia, atua como Coordenadora do Projeto Memória do Jornalismo Piauiense e do Núcleo de Pesquisa em Jornalismo e Comunicação e desempenha as funções de Professora e Coordenadora do Programa de Pós-Graduação em Comunicação da UFPI.
}

los Medios de Comunicación y el Periodismo han trabajado juntos, en un primer momento, defendiendo lo que creían como una defensa de la Democracia, posteriormente cambiando de posición y siendo perseguidos. Pocos han logrado mantenerse activos - uno de ellos fue Carlos Castello Branco, en su Coluna do Castello, en el Jornal do Brasil (JB). Así es que se analiza el Periodismo como un lugar de memoria, a partir del pensamiento de NORA (1984, 1993, 2008 y 2011) y RICOEUR (2012), y desde la análisis del papel del Periodismo en este panorama, en especial de Carlos Castello Branco, del jornal O Dia y del magazine Veja.

Palabras clave: Dictadura Militar; Periodismo; Lugar de memoria; Carlos Castello Branco

\section{Introdução}

Uma confluência de fatores imbricados em um complexo panorama geopolítico mundial em que os ditames da guerra fria que opunha dois sistemas: capitalismo e socialismo, e suas ideologias; culminou com a divisão do mundo em dois grandes polos, logo após a segunda guerra mundial. Esse cenário de disputas polarizadas em torno dos Estados Unidos e da União das Repúblicas Socialistas Soviéticas terminou por impor posicionamentos e ocasionou ingerências políticas internacionais em vários países. No Brasil, o processo acarretou no golpe militar de $1964^{2}$.

2 Vale ressaltar que desde o Governo de Jânio Quadros que o inconformismo dos militares era visível representando o pensamento conservador nacional. O restabelecimento das relações diplomáticas com a União Soviética e a aproximação com Cuba e China, através do então Vice-Presidente João Goulart, colocam o Brasil em visibilidade no cenário internacional. Ainda em 1961, quando da renúncia de Jânio Quadros, os militares impedem a posse de João Goulart como Presidente, que somente assume o cargo em setembro de 1961, após a aprovação pelo Congresso de uma emenda constitucional que implantou o regime parlamentarista no Brasil. João era Presidente, portanto, o Chefe de Estado, mas o Governo seria exercido por um "Primeiro-Ministro". Essa situação permaneceu até janeiro de 1963 quando se realizou um plebiscito em que o sistema presidencialista foi restaurado e João Goulart passou a finalmente exercer as funções de Chefe de Governo. Suas ideias lançadas no Plano Trienal deveriam ser acompanhadas por reformas estruturais profundas abrangendo quatro categorias: agrária, tributária, financeira e administrativa. A proposta era modificar radicalmente a distribuição de renda no país, promovendo a reforma agrária e o que denominava de reforma urbana. Todavia, o Plano não possuía o apoio internacional, sobretudo, norte-americano, o que inviabilizava a negociação da dívida externa e a entrada de novos capitais no país que pudessem financiar as reformas propostas. Com clara opção por um governo de esquerda, João Goulart impunha a seus discursos um tom nacionalista e claramente antiamericano, ao tempo, em que se posicionava contra a elite e as Forças Armadas. 
A mídia e o jornalismo tiveram participação considerável no processo que levou o país a ser governado pela força militar, deflagrando um estabelecimento político que se prolongaria até a década de 1980 e, no qual medidas arbitrárias e crescentes terminaram limitando os poderes civis, cerceando as liberdades, coibindo as manifestações políticas e culturais e direcionando a opinião do povo brasileiro para um consenso forjado em torno de como se deveria pensar o país.

O "milagre econômico", a cooptação dos grupos de mídia e a instituição da censura no jornalismo e nas manifestações artísticas, assim como, a intervenção estatal na condução da educação com a criação de novas disciplinas que tinham como objetivo desenvolver uma educação cívica nos moldes conservadores objetivando formar nos futuros cidadãos um pensamento em que o conservadorismo preponderasse; são algumas medidas, dentre inúmeras outras, tomadas pelo militares para criar consensos em torno de suas propostas de governo e do modelo de desenvolvimento para o país.

Diante desse cenário e objetivando atender a proposta da mesa cujo tema é Repressão e resistência na mídia, procuramos abordar a ditadura militar no jornalismo de seu próprio tempo a partir de um olhar guiado pelo conceito de lugar de memória cunhado por Nora ${ }^{4}$ (1993) e pontuado pela crítica de Ricouer (2012, p.100). Diante dessa escolha definimos como objeto de análise, primeiramente, o jornalismo praticado por Carlos Castello Branco ${ }^{5}$ em sua Coluna do Castello no Jornal do

3 O Milagre Econômico coincide com o período que vai de 1969 a 1973 em que a ditadura militar implanta o Programa de Ação Econômica do Governo-PAEG alavancado por empréstimos internacionais. O "milagre" se refere ao rápido crescimento econômico que ocasionou um aumento de renda para a sociedade brasileira, assim como, impulsionou diversos setores da economia nacional.

4 Denominado de historiador da memória (BREFE, 1999), Pierre Nora cria o conceito de lugares de memória na empreitada de realizar uma história da memória nacional francesa a partir dos espaços que guardavam a memória cívica da nação. "Assim, entre 1978 e 1979, eu me deixei flanar longamente entre temas diferentes uns dos outros que começavam com memoriais completamente verdadeiros como o Panteão, como o monumento aos mortos [...] e pouco a pouco entre temas que tinham relação com esses memoriais para mim evidente, mas não tão evidente para o grande público, por exemplo, o que a bandeira francesa, o que um emblema, uma instituição como a Academia Francesa, [...] transmitiam de expressão nacional de memória[...]. Eu me dei conta de que nunca fora feito a história da maior parte desses objetos, inclusive do Panteão [...] Eu acredito que um dos efeitos dos lugares de memória não foi somente de inventar temas, mas de lhes dar um brilho, uma centralidade que nunca tiveram ( NORA apud BREFE, 1999, p. 15).

5 Carlos Castello Branco foi um jornalista piauiense que esteve atuante no cenário nacional por mais de quatro décadas, tendo sido Secretário de Imprensa de Jânio Quadros. Castelinho, como era conhecido, comandou a Coluna do Castello no Jornal do Brasil por 30 anos. Ainda hoje Carlos Castello Branco é reverenciado como o maior jornalístico
Brasil. Para completar o processo de observação e objetivando dar visibilidade a construção de um consenso e de uma memória forjados na confluência das relações entre mídia e Estado ditatorial, apresentamos o jornalismo em outros periódicos como o jornal O Dia do estado do Piauí e a revista Veja.

É o jornalismo um lugar de memória? (Ponderações a partir da observação do contexto da ditadura militar e sua visibilidade no jornalismo)

O manifesto do governador Magalhães Pinto, recebido com euforia pela oposição e com desafogo pelo PSD, ao qual se ofereceu um novo polo de poder, repercutiu ontem na Câmara dos Deputados como o episódio decisivo da mobilização de forças para conter o presidente João Goulart [...] Sabe-se que o governador Magalhães Pinto, antes de divulgar seu manifesto, guarneceu as fronteiras do estado [...] Com a relativa segurança dessas horas de crise, informa-se igualmente que o presidente João Goulart estaria em face de um ultimato dos comandos militares com referência à punição dos subalternos da Marinha prestigiados pelo governo [...] Muitos políticos não hesitavam em prever uma renúncia do presidente nas próximas horas, como recurso tático para desencadear uma resistência.

(Coluna do Castello, Jornal do Brasil, 31 mar. 1964)

O trecho da Coluna do Castello que escolhemos para iniciar esse item analítico é emblemático ao nos repassar as impressões do jornalista Carlos Castello Branco no Jornal do Brasil, publicadas exatamente no momento em que os militares tomavam o poder no Brasil. O texto contém o discurso de um personagem da mídia com fortes ligações com o poder. Castello havia sido secretário de Imprensa de Jânio Quadros, período durante o qual intensificou contatos com os agentes do poder no campo ${ }^{6}$ político brasileiro de então. Seu discurso guardado nas páginas impressas do JB é singular e reflete não político do Brasil no século XX ( RÊGO, 2007).

6 Conceitos de Campo e de Agentes tomados conforme Bourdieu (1998) e (2005). 
somente a tensão vivida pelo país naqueles dias como se pode visualizar nas palavras: “ [...] Com a relativa segurança dessas horas de crise, informa-se igualmente que o presidente João Goulart estaria em face de um ultimato dos comandos militares com referência à punição dos subalternos da Marinha prestigiados pelo governo [...]"; mas o seu jornalismo ao ser acessado hoje 50 anos após sua publicação, serve como exemplo de um lugar de memória disponível, um lugar aonde a memória não está cristalizada, mas encontra-se aberta para ser trabalhada. Contudo, como veremos, o uso do termo é polêmico.

Pierre Nora após a conclusão da obra Les Lieux de Mémorie ${ }^{7}$, constata que embora tenha buscado trabalhar os lugares de memória e toda a obra citada na contramão dos processos comemorativos de uma memória nacional francesa, ela, a obra, terminara por ter sido apropriada pelo processo de comemoração que se instaurara na França (NORA, 2008, p.167). Por outro lado, a concepção de lugares de memória, apropriada na historiografia e em outras áreas, terminou sendo tanto pulverizada ${ }^{8}$ e de certa forma banalizada, como também, recebeu críticas, até porque sofreu, durante a extensão da obra, mutações impostas pelo próprio autor.

No texto de abertura do volume inicial de Les lieux de mémoire, intitulado Entre Memória e História: a problemática dos lugares ${ }^{9}$, Nora destaca que a sociedade contemporânea é marcada por uma anulação da memória pura, “[...] Desde que haja rastro, distância, mediação, não estamos mais dentro da verdadeira memória, mas dentro da história" (NORA, 1993, p.9). O autor enfatiza o que denomina de processo de desmoronamento da memória em todo o mundo, consolidado a seu ver, pela mundialização, democratização, massificação e midiatização, que conjuntamente ocasionaram o fim das sociedades de memória cuja conservação e transmissão dos valores se fazia por meio de instituições, tais como família ou escola, igreja ou Estado ( NORA, 1993, p.8). Vai mais além e confirma a morte das ideologias da memória como as que asseguravam a passagem regular do passado ao futuro. Para Nora foi o modo de ver a história que se dilatou por meio da mídia e substituiu "uma memória voltada para a herança de sua própria intimidade pela película efêmera da atualidade" (NORA, 1993, p.8).

7 Obra publicada em sete volumes.

8 Nora (apud BREFE, 1999, p.20) afirma que não acredita que a noção de lugares de memória do modo como ele o concebeu pudesse ser exportado para além dos limites da França, visto que o mesmo está intimamente relacionado ao modo como o povo francês se relaciona com seu passado a partir dos lugares construídos para a vivificação da memória nacional.

9 Nora afirma que o texto publicado inicialmente foi concluído somente ao final da obra (NORA apud BREFE, 1999, p.16).
Esse ponto é tomado por alguns autores como decisivo para não se considerar a mídia ou o jornalismo como um lugar de memória, visto que seu discurso se processa na confluência de disputas políticas, econômicas, etc. Entretanto, a nosso ver é exatamente a processualidade jornalística que se manifesta a partir de disputas e negociações de sentido que se operam no espaço midiático e forjam enquadramentos de memória, que reforça o seu caráter mnemônico, pois se coloca a posteriori de seu tempo de construção, como um suporte disponível para retorno e ressignificação histórica.

Há que se considerar que Nora (1995, p.179193) ao tratar do retorno do acontecimento imposto pelos meios de comunicação, ressalta o predomínio de uma história contemporânea pautada pela que chama de ditadura do acontecimento. Portanto, em sua concepção, são os meios de comunicação que impõem ao presente uma dimensão histórica. Enquanto em outro momento, assinala que a memória é essencialmente oral e afetiva e se fragmenta em uma pluralidade de narrativas. Logo, para ele, o que se denomina hoje de memória é na verdade história (NORA, 1993). Assim, os meios de comunicação e o jornalismo em si, guardariam na concepção de Nora a própria história e não a memória.

Ainda no texto sobre a problemática dos lugares, Nora conceitua os lugares de memória como depósitos de restos e vestígios, compondo-se do que o autor chama da "forma extrema onde subsiste uma consciência comemorativa de uma história que a chama" (NORA, 1993, p.12). Esse trecho é um dos que mais suscitam críticas e levam a entendimentos equivocados, como a apropriação pelo pensamento comemorativo.

Para o autor, esses espaços estão muito mais ligados aos sentimentos sociais e à necessidade de afirmação identitária do que a uma vontade de uma memória espontânea. Os lugares de memória são marcadores de um pretenso dever de memória social, mas também de memória individual que faz de cada um, "um historiador de si mesmo" ( NORA, 1993, p.17).

Contudo, os lugares de memória adquirem em Nora uma dimensão que ultrapassa o domínio do físico e se revestem sempre de três sentidos imprescindíveis para sua existência, qual sejam: o material, o funcional e o simbólico. Para este autor, mesmo

[...] um lugar de aparência puramente material, como um depósito de arquivos, só é lugar de memória se a imaginação o investe de uma áurea simbólica. Mesmo
23 
um lugar puramente funcional, como um manual de aula, um testamento, uma associação de antigos combatentes só entra na categoria se for objeto de um ritual (NORA, 1993, p.21).

Ainda para o autor em pauta, o que constitui os lugares de memória é tão somente um jogo de memória e de história, que inicia com a vontade de memória sem a qual os lugares de memória se tornam somente lugares de história.

Assim é que para nós, e extrapolando o campo de observação para os lugares limitado por Nora, o jornalismo se constitui como um lugar de memória, visto que a partir de novos olhares sobre o texto jornalístico em um momento posterior a seu tempo de produção, o jornalismo continua, mesmo situado no passado e falando sobre um determinado presente do passado; a reunir as três condições essenciais de consolidação de um lugar mnemônico, ou seja: material, simbólica e funcional. Embora a questão funcional seja modificada pela temporalidade adquirida, podendo até, como afirma Ricouer (2012), ser apagada pela história.

Vale dizer que não consideramos a história como encerrada no passado, ao contrário e sim que a partir da relação dialógica entre passado e presente, nela o jornalismo continua a contribuir na posteridade com a memória e com a história.

Posteriormente, Nora esclarece que os lugares de memória não se constituem em essência como repositórios $^{10}$, contudo, se colocam como lugares de trabalho da memória, "os lugares de memória não são aquilo a partir do que se lembra, mas lá onde a memória trabalha; não a tradição mesma, mas seu laboratório" (NORA, 1984: X). O que reforça profundamente a situação do jornalismo como um lugar de memória.

Por outro lado, ainda em seu texto inicial e em tom de crítica, o autor mencionado afirma que o interesse pela memória está relacionado ao nosso tempo, marcado por uma articulação em que se confunde a ruptura com o passado com um sentimento de memória esfacelada. Logo se criam lugares de memória porque não há meios de memória. Esses lugares de memória carregam em si o sentimento de continuidade (NORA, 1993, p.7). Posteriormente, o autor alarga o conceito fazendo com o mesmo abarque "[...] todo sistema de signos, contanto que seja uma unidade orgânica e que seja portador de uma memória" (NORA, 2011, p. 445). O que mais uma 10 A banalização do termo levaria a este entendimento, de espaço físico e depósito de quaisquer artefatos de memória nacional francesa. vez reforça a situação do jornalismo como um lugar de memória.

Mas é a defesa que realiza Ricouer (2012, p.100) da memória como a guardiã da problemática da relação representativa do presente com o passado, que efetivamente nos convence a manter o jornalismo como um lugar de memória.

Ricouer (2012, p.412) qualifica os lugares de memória de Nora como insólitos, atestando e apontando o que fez com que o conceito fosse apropriado pelo caráter comemorativo de uma memória nacional, fato que Nora não pode evitar, haja vista, sua proposição de realizar uma história de memória nacional francesa a partir da memória dos lugares. Este autor realiza crítica fundamentada ao analisar os textos de Nora contidos na obra Les Lieux de Mémorie, enfocando diversos aspectos da obra mencionada.

Entende-se que não se trata aqui, unicamente, nem mesmo principalmente, de lugares topográficos, mas de marcas exteriores, como em Fedro de Platão, nas quais as condutas sociais podem buscar apoio para suas transações cotidianas. Assim, os primeiros lugares citados no tomo I são o calendário republicano, representação externa do tempo social, a bandeira, emblema nacional oferecido a todos. Tantos objetos simbólicos de memória, como a Bandeira Tricolor, os Arquivos, as bibliotecas, os dicionários, os museus, assim como as comemorações, as festas, o Panteão ou o Arco do Triunfo, o dicionário Larousse e o Muro dos Federados. Tantos objetos simbólicos de memória oferecidos como instrumentos de base do trabalho histórico. Os lugares de memória são, eu diria, inscrições, no sentido amplo atribuído a esse termo em nossas meditações sobre a escrita e o espaço. Essa abertura da noção deve ser enfatizada desde o início, pois é seu achatamento nas localidades territoriais, graças à metamorfose patrimonial da identidade nacional, que tornará possível essa captura do tema pelo espírito de comemoração que será deplorado pelo artigo de 1992. No início, a noção, em virtude de sua envergadura, não está a 
serviço da memória, mas da história: "Há lugares de memória porque não há mais meios de memória", é a franca declaração que saúda a entrada da noção ( op.cit.p.XVII). Certamente, é em lugares que "se cristaliza e se refugia a memória (ibid), mas trata-se de uma "memória dilacerada", cujo dilaceramento, não é, na verdade, tão completo que a referência à memória possa ser apagada. Nela, o sentimento da continuidade é simplesmente "residual". "Os lugares de memória são, primeiramente, restos" ( op.cit.p.XXI). Dessa ambiguidade inicial virão os deslizamentos ulteriores da noção. O lugar extrai sua função da ruptura e da perda citadas: "Se ainda habitássemos nossa memória, não precisaríamos consagrarlhes lugares" (op.cit.p.XIX). [...] De fato, os lugares continuam a ser lugares de memória, e não de história (RICOUER, 2012, p.415-416, grifo nosso)

Ricouer destaca ainda a complexa estrutura dos lugares de memória de Nora, já mencionadas anteriormente, ou seja, as características material, simbólica e funcional. No que concerne ao ambiente material ele menciona que se refere a realidades dadas e manejáveis. Já a dimensão simbólica seria obra da imaginação e garantiria a cristalização das lembranças, ao passo que a funcional, todavia seria destituída pela história (RICOUER, 2012, p.416).

Por outro lado, as críticas de Ricouer recaem sobre a questão do que denomina de "malefício da patrimonialização", que em seu modo de ver não foi bem abordado por Nora. E conclui:

Então, a noção de lugares de memória foi, no final das contas, mal escolhida? Uma sombra passa sobre o termo e por sua “aliança aparentemente contraditória de duas palavras, uma delas dando ideia de afastamento e a outra, de aproximação (op.cit.p.1011). O historiador, não quer, todavia, se perder no pesar e na nostalgia. Ele prefere a réplica altiva (RICOUER, 2012, p.421).

Diante do exposto, voltamos a nos perguntar se o jornalismo se configura realmente como um lugar de memória, ou se poderia se situar como um lugar de história, uma vez que na contemporaneidade segundo Nora (1995, p.181-182) são os responsáveis pela predominância da história sobre a memória, uma vez que não apenas privilegiam o acontecimento, mas constituem o próprio meio de existência desses. Todavia, entendendo a memória histórica como uma sucessão de acontecimentos escolhidos para o campo da historiografia, porque guardam em si a singularidade que a história exige e, considerando que o jornalismo trabalha também com o singular, entende-se o posicionamento de Nora ao responsabilizar os meios de comunicação pelo monopólio da histórica, contudo, o jornalismo guarda muito mais do que os acontecimentos singulares, guarda diversos pontos de vista sobre esses acontecimentos e mais ainda, termina reunindo em seu discurso narrativas do cotidiano que embora singulares no momento de sua noticiabilidade, não possuem dimensão de fato histórico, logo o jornalismo atua sobre a memória coletiva e com esta se relaciona simbioticamente.

Podemos ainda interrogar se a noção é de fato adequada ao texto jornalístico a ser manipulado no presente $^{11}$ ou no futuro por historiadores e pesquisadores. Acreditamos que sim. Não se trata da tomada dos suportes jornalísticos no momento de sua construção em que a temporalidade da categoria se impõe ao presente, trata-se de uma análise a qualquer tempo, em que se considerará o tempo presente de sua construção já situado no passado, a partir de um presente de observação. Enquadradas, manipuladas ou somente trabalhadas, o jornalismo guarda em si, memórias sociais que podem ser acessadas a qualquer tempo e que não se encontram cristalizadas, mas fazem parte de um jogo em que podem ser confrontadas e até modificadas. Ficamos assim com a escolha de Ricouer (2012) para quem os lugares de memória continuam como de memória e não como de história como ventila Nora (1993), por outro lado, temos consciência de que estamos ultrapassando as posições do autor mencionado por último, mas conservando parte de seu detalhamento e características ao adotarmos a noção de lugar de memória.

Confirmando minhas escolhas, Jacques Le Goff (2003, p.471) atribui ao jornalista o status de profissional da memória ao lado de historiadores, antropólogos e sociólogos. Concordo com ele quando, por exemplo, leio que o escreveu Castelinho em sua coluna

11 Considerando que a presentificação do discurso jornalístico a partir de uma necessidade de novidade imperiosa e inerente à prática da profissão, empurra para o passado os fatos numa velocidade cada maior e potencializada pelas possibilidades tecnológicas. O presente torna-se instantâneo e as novidades se tornam obsoletas. Logo mesmo no presente contemporâneo a narrativa jornalística entendida enquanto informação nova, já é passado no momento de sua publicação (RÊGO, 2012).
25 
no dia 14 de dezembro de 1968, logo após a publicação do Ato Institucional de número 5:

Ao Ato Institucional de ontem não deverá seguir-se nenhum outro ato institucional. Ele é completo e não deixou de fora, aparentemente nada em matéria de previsão de poderes discricionários expressos. A experiência do governo Castello Branco, que teve de editar atos desse tipo quatro vezes, terá aproveitado ao redator do novo édito.

Ele cobre perfeitamente as previsões dos deputados mais íntimos do processo revolucionário, que antecipavam uma peça destinada a munir o governo dos instrumentos para tudo o que por timidez ou por compromisso democrático deixou de fazer, nos dias quentes da Revolução de março, o presidente Castello Branco.

O Congresso posto em recesso por tempo indeterminado, está praticamente fechado e tudo indica que se cumprirão as profecias de que um expurgo no Poder Judiciário. A possibilidade, mantida pelo Presidente, de convocar o Congresso sem compromisso de data indica que somente para resolver uma crise eventual ele o fará. Mais provavelmente, contudo, Câmara e Senado somente voltarão a se reunir para constituir Colégio Eleitoral que, no tempo próprio ou no momento designado pela revolução, formalizará a escolha do sucesso do Presidente Costa e Silva.

$[\ldots]$

A imprensa aparentemente foi poupada. $\mathrm{Na}$ realidade, deverá o tema ser tratado num ato complementar, tal como antecipavam ontem os deputados do esquema situacionista.

$[\ldots]$

A medida estancou todas as fontes políticas de resistência ao Governo, não deixando nenhuma válvula. A Oposição não terá a menor possibilidade de produzir-se, a não ser que seja respeitada, e até quando o for, a liberdade de imprensa. Mesmo assim os políticos de tal modo contidos que seu acesso aos jornais importará num risco certo para cada um deles.

As instituições criadas pela Constituição de 1967 podem retornar um dia. No momento, elas estão suspensas, apesar de ter sido mantida formalmente a Constituição.

[

Quanto à execução do Ato, é agora questão de tempo. O Presidente Castello Branco usou parcimoniosamente de seus poderes discricionários. O Presidente Costa e Silva tem a imagem de homem moderado e de sentimentos humanitários. Resta saber se terá condições de exercer com a mesma moderação do seu antecessor os tremendos poderes de que se investiu após tanta hesitação.

(Coluna do Castello, Jornal do Brasil, 14 dez. 1968)

Obviamente que a leitura da Coluna do Castello durante a ditadura ou em qualquer período, assim como, de qualquer conteúdo jornalístico, não pode ser acrítico, ao contrário tem que considerar as condições de sua produção e o lugar social ( CERTEAU, 2011) ocupado pelo jornalista no cenário político de então. Como dito antes, Castelinho se tornou amigo de políticos e militares que lhe alimentavam de informações sobre os bastidores do poder e, embora, tenha sido detido várias vezes como atestou em várias ocasições sua esposa Elvia Castello Branco, conseguiu manter sua coluna durante o período mais negro da ditadura, sempre divulgando e denunciando abertamente ou por meio de metáforas, os desmandos que ocorriam em diversos setores do governo militar. A Coluna do Castello é lembrada por muitos políticos que vivenciaram a época como um dos poucos lugares em que a liberdade de imprensa era praticada, mesmo assim, de forma comedida. Na grande maioria dos periódicos e jornais televisivos, a divulgação das ações governamentais se dava de forma contumaz de modo a convencer a nação de que nada havia de errado com os rumos e com o ritmo de progresso que os militares impunham ao país.

No Piauí, por exemplo, vamos localizar em um dos jornais de maior circulação, matérias que colocavam o claro posicionamento do jornal em favor do regime, tais como as manchetes :"Castelo Branco eleito Presidente 
da República por esmagadora maioria” (O Dia, 12 abr. 1964); "Nação inteira confia no novo Presidente" (O Dia, 17 abr. 1964); "Mulheres rezam contra o Comunismo"( O Dia, 15 mar. 1964) ; “Terror Comunista” (O Dia, 11 abri. 1964); “Todo o Piani tranquilo" (O Dia, 17 dez. de 1968) (OLIVEIRA FILHO e RÊGO, 2013).

O exemplo do jornal O Dia reflete a construção do consenso nacional forjado. A reportagem sobre as mulheres rezando contra o comunismo em ato público realizado no Rio de Janeiro, publicada poucos dias antes do golpe, se multiplica em muitas outras após o golpe como que justificando a opção dos militares ao salvar o Brasil de João Goulart e de sua ideologia "comunista”. A matéria sobre o Piauí tranquilo após a publicação do AI 5 é emblemática pois atesta que o estado confiava mais do que nunca nos rumos que o governo militar impunha ao país, embora já vigorasse um regime de total exceção. A ação direta dos políticos conservadores e militares na mídia, foi no sentido de se construir no imaginário simbólico do povo uma imagem do perigo que o Presidente João e seus aliados como Leonel Brizola, representavam ao propor a reforma agrária e ao desejar a redistribuição de renda para a nação. Assim como, de trabalhar em prol da construção de imagem positiva para o regime.

A revista $V_{e j a}$ em sua primeira edição publicada em 11 de setembro de 1968 traz uma chamada de capa em que se lê em um fundo vermelho, em que preponderam em preto, a foice e o martelo ${ }^{12}$ o título: $O$ grande duelo no mundo comunista. A edição apresenta uma reportagem sobre a URSS em que detalha os problemas passados pela Rússia e seus aliados na guerra fria que se desenrolava. A matéria intitulada Rebelião na Galáxia Vermelha mostra a dificuldade da URSS de se manter como a principal nação do bloco que lhe rodeava. O tema da guerra fria e o posicionamento brasileiro firmado definitivamente após o golpe de 1964 guiam o tom da matéria que busca desqualificar a URSS e o comunismo, a que eram simpáticos João Goulart e correligionários.

Desde que a galáxia foi formada, o Kremlin tem se esforçado, por diversas maneiras, para ser o sol único e incontestado. Aos países que lhe giram em volta, nem sequer foi reconhecido até hoje o papel de planetas: de fato, no Ocidente, eles são chamados de satélites. Entretanto, nem tudo tem ocorrido de acordo com os planos do Kremlin: os satélites, ora um, ora outro ensaiam há tempos a sua revolução. E o sol, a cada vez, fica menos luminoso.

(Veja, ano 1, no 1, 11 set 1968, p.86).

Emblemático também é o posicionamento da mesma publicação (Veja) que em edição publicada após o AI 5 apresenta uma extensa reportagem em que revê as posições governamentais desde momentos antes do golpe. A matéria que tem como epígrafe a frase: Com um Ato Institucional mais forte, Costa e Silva anuncia um novo estilo, analisa desde os últimos momentos de Goulart na Presidência até a publicação do referido Ato Institucional.

Um ato de análise

O Ato Institucional não deixa de ser uma autocrítica da Revolução, onde o partido do governo não escapa a uma censura no preâmbulo. E, na decretação do recesso do Congresso por tem indeterminado está o sinal mais evidente de uma nova fase em que a Revolução se reinicia sem a classe política que não quis ou não pode integrar-se no processo revolucionário. A manutenção da Constituição de 1967 tem o efeito de manter também o mesmo sistema de escolha do Presidente da República [...] O dia 13 de dezembro, para os militares, passa a constituir o Ano Zero da Revolução [...].

(Veja, ano I, nº15, 18 dez 1968)

Como bem diz Le Goff (2003) a memória é um elemento essencial e constituidor das identidades. Logo a relação de poder concorrencial se estabelece uma vez que todos que objetivam dominar as sociedades procuram se tornar senhores da memória e do esquecimento. "Os esquecimentos e os silêncios da história são reveladores destes mecanismos de manipulação da memória coletiva ( LE GOFF, 2003, 422).

Na matéria A Esperança dos Cassados publicada em Veja de 02 de outubro de 1968 que se referia aos processos contra os ex-Presidentes Juscelino Kubitschek, Jânio Quadros e João Goulart, Veja destaca ao comentar sobre a condenação de Jânio Quadros que seu crime teria, tão somente, falar de política. A Revista que na época ainda não estava sujeita aos ditames da censura

12 Símbolos do Comunismo. 
que seria instaurada posteriormente, tanto apresenta comentários em forma de denúncia sobre os atos do Supremo Tribunal, como também, reflete outras falas que defendem a não existência de ditadura militar no Brasil, como podemos conferir:

Comentando as decisões do Supremo, o Senador Daniel Krieger, líder do governo no Senado e presidente nacional da Arena, garantia que elas confirmam o óbvio: "estamos numa democracia onde o Judiciário se sente respeitado e, por isso, suficientemente forte para decidir inclusive matéria de alto conteúdo político. Os que pregam a existência de ditadura militar no Brasil estão muitos alegres com outra decisão do Supremo, mas não percebem que isso é uma contradição: se o Tribunal liberta um líder estudantil que diz lutar contra a ditadura, é sinal de que a ditadura não existe". Outros, principalmente, na área oposicionista raciocinam de modo diverso: a tradição brasileira sempre foi a de encerrar os períodos de exceção subsequente às situações revolucionárias com atos de anistia que acabam por reconduzir à "normalidade político-institucional". Como dessa vez esse caminho se mostrava fechado, tanto na área do Executivo como do Legislativo, competia ao Judiciário abrir passagem pelo atalho da jurisprudência. Sob esse aspecto, logo depois de ser anulada a condenação de Darcy Ribeiro a três anos de prisão, alguns meios políticos consideraram a decisão como "meia anistia".

(A Esperança dos Cassados, Veja, 02 out. 1968)

Como dito anteriormente, Nora ao analisar o retorno do fato, esclarece que são meios de comunicação os responsáveis pelo reaparecimento do monopólio da história, para ele o monopólio da história é da mídia. "Nas nossas sociedades contemporâneas é por intermédio deles e somente por eles que o acontecimento marca a sua presença e não nos pode evitar" (NORA, 1995, p.181). Os meios de comunicação visibilizam acontecimentos enquanto relegam outros à condição de esque- cimento e ao fazerem isso dão aos fatos visibilizados o status de históricos por natureza ${ }^{13}$. Todavia, quando em momentos de censura e manipulação da mídia e do jornalismo, os discursos são direcionados e a memória é enquadrada, por vezes construída e deturpada, vale recorrer a outros espaços, fontes e vestígios para confrontar uma memória midiática/jornalística que não perde seu lugar, mas que necessita ser retrabalhada para se aproximar de uma condição de verdade.

É de domínio público que a ditadura militar reestabeleceu a censura em nosso país, sabe-se que o regime endureceu a partir de 1968 e que os anos de Médici foram bem difíceis para o jornalismo, que guarda em si, as marcas da censura cunhadas em suas páginas, seja pela visibilidade da oficialidade estatal ou pela imposição de esquecimento. A censura, no entanto, foi sendo implantada de forma paulatina até que o regime militar tivesse domínio do que se publicava no país. Quando hoje acessamos as páginas dos jornais de então podemos ter ideia do que de fato se viveu naqueles anos, a partir de uma articulação entre os suportes e contextos de memória e história que se articulam para nos permitir mergulhar nesse universo.

Em 01 de janeiro de 1971, Carlos Castello Branco publica em sua coluna um longo comentário intitulado: Nova ameaça à Liberdade em que comenta sobre o cerceamento à liberdade de imprensa, como podemos conferir:

Passou quase despercebida a instrução sobre "verificação prévia de livros e periódicos, assinada no dia 11 pelo Ministro da Justiça, mas somente publicada no Diário Oficial do dia 29, que circulou anteontem. E, no entanto, se trata de assunto importante. Na verdade, da maior importância para o país, que pretende se desenvolver em liberdade.

"Verificação prévia", expressão nova e inadequada, em realidade quer dizer censura prévia [...]

A instrução não tem mais do que dois artigos. No primeiro diz que a "verificação prévia" de periódicos será feita "um exemplar já impresso com todas as características de publicação a ser exposta à venda pública”. O Artigo $2^{\circ}$ diz que a censura de livros " poderá ser feita em original datilografado", ou seja, mais ou

13 Contudo nem tudo o que é divulgado pela mídia possui status de histórico, como visto anteriormente neste texto. 
menos conforme o processo que vinha sendo usado também para a "verificação" de periódicos[...]

A modificação de fato só ocorre em relação aos periódicos, é muito mais profunda do que pode parecer aos que não conhecem a complexidade e urgência da indústria jornalística que tem tempo certo e inadiável para apresentar o seu produto. (Coluna do Castello, Jornal do Brasil, 01 jan.1971)

Ao acessarmos as palavras do jornalista guardadas no suporte informacional nos confrontamos com possibilidades interpretativas que se articulam a partir das memórias, visando trazer para visibilidade processos que desejamos ou precisamos ressignificar.

Creio que esse é o exercício que se deve fazer toda vez que se recorre ao jornalismo como um lugar de memória el ou como fonte e até mesmo como objeto de pesquisa histórica ${ }^{14}$. Nunca considerando como absoluto o discurso que lá se encontra. Portanto, reconhecendo que a memória carrega em si, aspectos intrínsecos de flexibilidade, visto que se forma, deforma e reforma, conforme se assimilam outras memórias e histórias.

Há momentos e são muitos, no entanto, em que o jornalismo trabalha em prol do esquecimento ou revela algo que não deixava transparecer em momentos anteriores. Nesse momento, a instituição que tem como dever a informação de relevância social trabalha para em prol dos abusos da memória. Segundo Ricouer os abusos da memória tem seu correspondente nos abusos do esquecimento. No caso da Lei da Anistia de 1979 temos uma lei que trabalha em prol do esquecimento. Como afirma Ricouer (2012, p.459) essa correspondência se estabelece sobretudo, quando formas institucionais de esquecimento se estabelecem, a exemplo da anistia que trabalha em linha tênue com a amnésia.

A lei da Anistia promulgada em 28 de agosto de 1979 concedeu "perdão" a todos os que entre 1961 e 1979 tenham cometido crimes políticos, aos que tiveram seus direitos cassados, aos funcionários públicos, aos militares e aos dirigentes e representantes sindicais punidos por Atos Institucionais anteriores. A referida lei perdoou ambos os lados da mesma forma. Segundo Ricouer a anistia põe fim a desordens políticas tais como processos

14 Segundo Lucca (2006, p.141) a utilização da imprensa periódica pelos historiadores e demais pesquisadores, faz dos impressos, a um só tempo, fonte e objeto de pesquisa historiográfica. revolucionários, guerras civis, etc. de forma intencional pelo poder institucional com vista a se restaurar a paz cívica.

Mas a anistia, enquanto esquecimento
institucional, toca nas próprias raízes
do político e, através deste, na relação
mais profunda e mais dissimulada com
um passado declarado proibido. A pro-
ximidade mais que fonética, e até mes-
mo semântica, entre anistia e amnésia
aponta para a existência de um pacto
secreto com a denegação de memória
que, como veremos mais adiante, na
verdade a afasta do perdão após ter pro-
posto sua simulação (RICOUER, 2012,
p. 460 ).

No momento de sua instituição a anistia causou insatisfação nos meios militares inconformados com a ideia de libertação dos presos políticos, uma vez que as forças armadas se consideravam responsáveis e teriam trabalhado duro para impedir que o país se tornar-se comunista. Algum tempo depois a anistia começou a ser contestada pela sociedade. Esse momento coincide com a restauração da democracia no Brasil e com o reconhecimento dos crimes cometidos pelo Estado brasileiro durante os governos militares. Essa posição se intensificou a partir do Governo da Presidente Dilma Rousseff, presa política na década de 1970.

Os debates e o movimento pró-anistia esteve presente nas esferas do poder e na mídia durante os anos de 1978 e 1979. Carlos Castello Branco em sua coluna de 23 de agosto de 1979 intitulada Anistia e suas frustaçoes, ressalta que foi necessário um movimento de grandes proporções para sensibilizar o então Presidente Figueiredo, "[..] a mobilização de opinião terminou por conduzir o Presidente e seu Governo a considerar a ideia da anistia como legítima por representar aspiração de largas correntes da opinião pública e por ser o pressuposto de uma política de conciliação que se propunha a levar a cabo".

Poucos meses antes, em sua coluna de 25 de maio do mesmo ano, Castelinho em cima das polêmicas geradas em torno da proposição de anistia e da insatisfação dos setores conservadores da sociedade para com a mesma, pondera que

Parece óbvio que se pretende recolocar o problema de modo a evitar a anistia 
propriamente e se retornar à superada fórmula inicial e imprópria da revisão de cassações e de processos. Já se sabe que isso é impossível. Ou vem a anistia ou nada virá e o compromisso do Governo é a anistia, com exclusão das pessoas acusadas de praticarem crimes de sangue.

( Coluna do Castello, Jornal do Brasil, 25 maio 1979)

Dia seguinte o jornalista comenta o mesmo tema, mas "afinal estamos com a anistia à porta, e isso é o que vale. O Presidente Figueiredo já não tem dificuldades a invocar e a anistia pode vir a amanhã como até mesmo poderia ter vindo ontem" (Coluna do Castello, Jornal do Brasil, 26 maio 1979).

Dois dias após a publicação da Lei, Castelinho analisa a postura dos militares insatisfeitos com o processo de abertura que parecia inevitável e no qual a anistia desempenha importante papel.

A sucessão de pronunciamentos militares, ocorrida nos últimos dias, deve ter um objetivo especial, qual seja oferecer uma compensação moral ao aparelho de segurança e repressão no momento em que o Presidente da Republica sanciona o projeto de lei aprovado pelo Congresso concedendo anistia a grande número de presos políticos. Essa certamente a intenção, que transparece das últimas declarações do chefe do Estado-Maior do Exército, a quem coube expressamente assegurar aos que "evitaram a comunização do Brasil” que "eles não serão esquecidos pelo desassombro com que cumpriram as missões".

$[\ldots]$

Como os generais estão apoiando os esforços do Presidente da República, é razoável que se perceba nos seus sucessivos pronunciamentos apenas a intenção de abortar reações internas nas corporações sob seu comando. Tratar-se-ia assim de manifestações últimas de um longo período em que a política, tendo sido banida do Congresso e dos Partidos, se recolhera aos quartéis. A missão militar foi, aliás, delineada com precisão pelo Comandante do III Exército, General Antônio Bandeira, quando disse que "estamos preparados para exercer; modestos e incógnitos, na caserna, a nossa missão, constitucional, de defender a pátria, garantir os Poderes constituídos, a lei e a ordem".

( Coluna do Castello, Jornal do Brasil, 30 ago 1979)

No mesmo texto Carlos Castello Branco afaga o ego dos militares e destaca sua importância para a nação.

A missão constitucional das Forças Armadas é relevante e nobre e, como o princípio basilar da instituição é a disciplina, o momento de agir e os objetivos da ação devem sempre ser traçados pelo Presidente da República, a quem cabe a responsabilidade final de manter as instituições e a ordem pública. Ele é quem, com as antenas ligadas, pode perceber o rufar dos "tambores vermelhos" e determinar em consequência operações para abafar o estranho ruído.

Em 1964, a ação das Forças Armadas foi amparada pelo diagnóstico feito por um dos poderes constituídos, o Congresso Nacional, de que estava sob ameaça de ser fechado por outro poder influenciado por agentes subversivos. Os poderes da República são três e naquele momento um deles pedia socorro, no que foi ouvido e atendido. O General João Figueiredo já se incumbiu de definir o objetivo de 1964 e as distorções ocorridas em seguida para proclamar o propósito do seu Governo de voltarmos às inspirações iniciais do Movimento de 1964, que era garantir os poderes constituídos, a lei e a ordem.

( Coluna do Castello, Jornal do Brasil, 30 ago 1979)

Encerrando as nossas observações sobre o jornalismo a partir das narrativas jornalísticas do período ditatorial, reforçamos nosso posicionamento anterior de 
tratar o jornalismo como um lugar de memória pronta pra ser trabalhada e negociada. Carlos Castello Branco atravessou os anos de governo militar atuando no Jornal do Brasil e conseguiu registrar através de seus comentários a memória política do Brasil. Vale ressaltar que o jornalista foi um observador extremamente privilegiado com uma rede de contatos nos aparelhos do poder, difícil de se estabelecer em quaisquer tempo. Esse lugar central nas relações de poder, lhe possibilitou uma visão dos diversos panoramas políticos vivenciados pelo país. É possível que seus pontos de vista estivessem, em certos momentos, contaminados pelo relacionamento direto com as fontes, uma vez que muitos políticos e militares tornaram-se amigos particulares do jornalista. Por outro lado, essa contaminação poderia vir a desqualificar o seu discurso como credível, o que não ocorreu; mas não o desqualifica enquanto memória, pois se coloca passível de revisão e de negociação para o pesquisador/historiador atento.

O jornalismo de Castelinho por suas características e aproximação com o poder, não se constitui como um jornalismo de resistência, mas se consolidou como um jornalismo de denúncias comedidas e esperanças nos momentos em que não existiam outros canais de liberdade de imprensa e opinião. Oscilando entre um tom mais radical e denunciador e uma abordagem mais apaziguadora, Carlos Castello Branco, conseguiu atuar em "corda bamba", sobretudo, nos anos do endurecimento ditatorial, em que foi detido vários vezes.

\section{Referências}

BOURDIEU, Pierre. O Poder Simbólico. Rio de Janeiro: Bertrand Brasil, 1998.

BOURDIEU, Pierre. As regras da Arte. São Paulo: Companbia das Letras, 2005.

BREFE, Ana Cláudia Fonseca. Pierre Nora: ou o historiador da memória. In:História Social. No 6. Campinas, SP, p. 13-33. Disponível em: http://www.ifch.unicamp.br/ ojs/index.php/rhs/article/viewFile/363/314 . Acesso em: 26 abr. 2014.

CERTEAU, Michel. A Escrita da história. Rio de Janeiro: Forense, 2011.

COLUNA DO CASTELLO, Jornal do Brasil, 31 mar. 1964. Disponível em: < http://www.carloscastellobranco.com.br/sec_coluna.php>. Acesso em: 20 abr.2014.
COLUNA DO CASTELLO, Jornal do Brasil, 14 dez. 1968. Disponível em: < http://www.carloscastellobranco.com.br/sec_coluna.php>. Acesso em: 20 abr.2014.

COLUNA DO CASTELLO, Jornal do Brasil, 01 jan. 1971. Disponível em: < http://www.carloscastellobranco.com.br/sec_coluna.php>. Acesso em: 20 abr.2014.

COLUNA DO CASTELLO, Jornal do Brasil, 25 mai. 1979. Disponível em: < http://www.carloscastellobranco.com.br/sec_coluna.php>. Acesso em: 20 abr.2014.

COLUNA DO CASTELLO, Jornal do Brasil, 26 mai. 1979. Disponível em: < http://www.carloscastellobranco.com.br/sec_coluna.php>. Acesso em: 20 abr.2014.

COLUNA DO CASTELLO, Jornal do Brasil, 23 ago. 1979. Disponível em: < http://www.carloscastellobranco.com.br/sec_coluna.php>. Acesso em: 20 abr.2014.

COLUNA DO CASTELLO, Jornal do Brasil, 30 ago. 1979. Disponível em: < http://www.carloscastellobranco.com.br/sec_coluna.php>. Acesso em: 20 abr.2014.

LUCA, Tânia Regina de. História dos, nos e por meio dos periódicos. In. BASSANEZI,

Carla Pinsky (Org.). Fontes históricas. 2 ed. São Paulo: Contexto, 2006.

LE GOFF, Jacques. História e Memória. São Paulo: Unicamp, 2003.

NORA, Pierre. Entre memória e história: a problemática dos lugares. Projeto História, São Paulo, n.10, dez. 1993, p.7-28.

NORA, Pierre. (dir.). Les lieux de mémoire - I: La République. Paris: Gallimard, 1984.

NORA, Pierre. Historien public. Paris: Gallimard, 2011.

NORA, Pierre. Pierre Nora en Les lieux de mémoire. Montevideo: Trilce, 2008.

NORA, Pierre. O Retorno do Fato. In: NORA, Pierre e LE GOFF, Jacques. História: novos problemas. Rio de Janeiro: Francisco Alves Editora S.A, 1995.

O DIA, Teresina, 12 abr. 1964, n 1214
31 
O DIA, Teresina, 17 abr. 1964, nº 1218

O DIA, Teresina, 15 mar. 1964, no 1194

O DIA, Teresina, 11 abr. 1964, nº 1213

O DIA, Teresina, 17 dez. 1968, no 2596

OLIVEIRA FILHO, Tertuliano Vicente e RÊGO, Ana Regina. "Todo o Piaui Tranquilo" com a revolução: vestígios da ditadura militar nas páginas do Jornal O Dia. In: $9^{\circ}$ Encontro Nacional de História da Mídia. Ouro Preto: UFOP, maio, 2013.

RÊGO, Ana Regina. Carlos Castello Branco e a opinião no jornalismo brasileiro. In: V Congresso Nacional de História da Mídia. São Paulo: Cásper Líbero, jun, 2007.

RÊGO, Ana Regina. Jornalismo e Memória: entre o tempo e a ética. In: $10^{\circ}$ SBPJOR- Encontro Nacional de Pesquisadores em Jornalismo. Curitiba: PUC, nov. 2012.

RICOUER, Paul. A memória, a história, o esquecimento. Campinas: UNICAMP, 2012.

VEJA, ano 1, nº 1, 11 set. 1968. Disponível em: < http:/ / veja.abril.com.br/acervodigital/home.asp $>$. Acesso em: 22 abr. 2014.

VEJA, ano 1, $\mathrm{n}^{\circ}$ 15, 18 dez. 1968. Disponível em: < http://veja.abril.com.br/acervodigital/home.asp>. Acesso em: 22 abr. 2014.

VEJA, ano 1, nº 4, 02 out.1968. Disponível em: < http:/ / veja.abril.com.br/acervodigital/home.asp >. Acesso em: 22 abr. 2014. 